\title{
STATUS TROPIK DAN ISI LAMBUNG IKAN NILA (Oreochromis niloticus) DARI WADUK WONOREJO, TULUNGAGUNG, JAWA TIMUR
}

\author{
Diana Arfiati $^{\mathrm{a}, *}$, Asthervina Widyastami Puspitasari ${ }^{\mathrm{a}}$, Diana Putri Renitasari ${ }^{\mathrm{a}}$, \\ Irawati Mei Widiastuti ${ }^{b}$ \\ ${ }^{a}$ Fakultas Perikanan dan Ilmu Kelautan, Universitas Brawijaya, Malang, Jl. Veteran No. 1 Malang, Indonesia \\ ${ }^{\mathrm{b}}$ Fakultas Peternakan dan Perikanan, Universitas Tadulako, Palu, Jl. Bumi Tadulako Tondo Palu, Indonesia \\ *Koresponden penulis :d_arfiati@yahoo.com
}

\begin{abstract}
Abstrak
Plankton merupakan salah satu jenis pakan alami yang berperan penting untuk pertumbuhan organisme akuatik terutama ikan. Tujuan dari penelitian ini adalah untuk mengetahui jenis-jenis plankton beserta kelimpahannya di perairan dan di lambung ikan nila yang tertangkap di Waduk Wonorejo, beserta aktivitas enzimatis lambung ikan nila tersebut. Penelitian ini bertempat di Waduk Wonorejo, Tulungagung, Jawa Timur dengan metode survei. Sampel diambil dari 2 stasiun, yaitu stasiun pertama di daerah wisata Waduk Wonorejo, sedangkan stasiun 2 berada di wilayah pemancingan umum Waduk Wonorejo. Plankton di perairan Waduk Wonorejo ditemukan 17 genus fitoplankton, dan 5 genus zooplankton, sedangkan di lambung ikan nila ditemukan 30 genus fitoplankton dan 2 genus zooplankton. Genus Spirogyra sp. merupakan genus yang paling tinggi kehadirannya baik di lambung maupun perairan Waduk Wonorejo. Kelimpahan plankton di perairan waduk dapat digolongkan oligotrofik dengan nilai kelimpahan plankton sebesar $1487 \mathrm{ind} / \mathrm{ml}$ di stasiun 1 dengan keanekaragaman tinggi dan $746 \mathrm{ind} / \mathrm{ml}$ di stasiun 2 dengan keanekaragaman sedang, serta tidak ada jenis plankton tertentu yang mendominasi di kedua stasiun tersebut. Analisis aktivitas enzim lambung ikan nila menunjukkan aktivitas enzim protease sebesar $0,84 \pm 0,02 \mu$ mol tirosin/g enzim menit; enzim amilase 14,59 \pm 1,07 $\mu$ mol glukosa/g enzim menit; enzim lipase 17,83 $\pm 0,14$ $\mu \mathrm{mol}$ asam lemak/g enzim menit. Kualitas air di Waduk Wonorejo tergolong baik dengan suhu berkisar 26,3-27,3 ${ }^{\circ} \mathrm{C}$, pH 7, DO 7,1-8,4 mg/L, Kecerahan 110-154 cm, TOM 19-30,3 mg/L. Maka dari itu upaya untuk mempertahankan kondisi Waduk Wonorejo agar tetap oligotrofik perlu dilakukan.
\end{abstract}

Kata kunci : ikan nila, plankton, waduk wonorejo

\begin{abstract}
Plankton is one type of natural feed that plays an important role in the growth of aquatic organisms, especially fish. The purpose of this study was to determine the types of plankton and its abundance in the waters and in the hulls of tilapia caught in the Wonorejo Reservoir, along with the gastric enzymatic activity of the tilapia. This research took place in the Wonorejo Reservoir, Tulungagung, East Java with a survey method. Samples were taken from 2 stations, the first station in the tourism area of Wonorejo Reservoir, while station 2 was in the general fishing area of the Wonorejo Reservoir. Plankton in the waters of the Wonorejo Reservoir found 17 phytoplankton genera, and 5 zooplankton genera, while in the tilapia stomach 30 found phytoplankton genera and 2 zooplankton genera. Genus Spirogyra sp. is the highest genus of presence in both the stomach and the waters of the Wonorejo Reservoir. Plankton abundance in reservoir waters can be classified as oligotrophic with plankton abundance value was 1487 ind / ml at station 1 with high diversity and 746 ind / $\mathrm{ml}$ at station 2 with moderate diversity, and no specific type of plankton dominates in both stations. Analysis of tilapia gastric enzyme activity showed protease enzyme activity was $0.84 \pm 0.02$ umol tyrosine / g enzyme minutes; amylase enzyme was $14.59 \pm 1.07$ umol glucose / $g$ enzyme minutes; lipase enzyme was $17.83 \pm 0.14 \mu$ mol fatty acid / $g$ minute enzyme. Water quality in the Wonorejo Reservoir was classified as good with temperatures ranging from 26.3-27.3 $\mathrm{C}, \mathrm{pH} 7, \mathrm{DO}$ 7.1-8.4 $\mathrm{mg} / \mathrm{L}$, Brightness 110-154 cm, TOM 19-30.3 mg/L. Therefore, efforts to maintain the conditions of the Wonorejo Reservoir to remain oligotrophic will be needed.
\end{abstract}

Keywords: plankton, tilapia, wonorejo reservoir 


\section{PENDAHULUAN}

Ikan nila merupakan salah satu komoditi perikanan yang potensial di Indonesia, hal itu disebabkan karena karakteristik ikan nila yang mudah memijah, pertumbuhannya cepat dan mudah beradaptasi [1]. Makanan favorit dari ikan nila (Oreochromis niloticus) berupa plankton baik fitoplankton maupun zooplankton [2]. Plankton merupakan organisme mikroskopik yang secara umum mengambang di perairan dan sangat sedikit pergerakannya. Plankton terdiri atas fitoplankton dan zooplankton. Fitoplankton diklasifikasikan dalam jenis tumbuhan mikroskopik yang dapat digunakan sebagai bioindikator kualitas suatu perairan [3]. Fitoplankton merupakan produsen pertama yang menggunakan faktor abiotik dan melalui proses fotosintesis untuk memproduksi energi [4]. Sedangkan zooplankton merupakan konsumen tingkat pertama yang mengkonsumsi fitoplankton dan merupakan pembatas antara fitoplankton dan konsumer yang tingkatannya lebih tinggi [5]. Beberapa faktor biotik dan abiotik seperti suhu, habitat, ada atau tidak nya ikan, dan makropita merupakan faktor-faktor yang mempengaruhi kelimpahan dan komposisi spesies zooplankton $[6 ; 7 ; 8 ; 9]$.

Waduk Wonorejo merupakan salah satu waduk dengan kualitas air yang baik dengan tinggi bendungan sebesar 65 meter dan memiliki volume tampung sebesar 106 juta $^{3}$ dengan debit air sebesar $15.000 \mathrm{~m}^{3}$ per detik dan bertempat di Kabupaten Tulungagung yang biasa dimanfaatkan untuk kegiatan perikanan berbasis perairan umum. Selain itu, Waduk Wonorejo digunakan sebagai obyek wisata dan juga digunakan sebagai pemenuhan kebutuhan produksi PDAM di Kota Surabaya guna diolah menjadi air minum [10].

Tujuan dari penelitian ini adalah untuk mengatahui jenis-jenis plankton dan kelimpahannya di Waduk Wonorejo berdasarkan kelimpahan plankton di perairan dan isi lambung di ikan nila yang dibandingkan dengan kualitas perairan tersebut, sekaligus pemeriksaan aktivitas enzimatis lambung ikan nila yang tertangkap untuk mengetahui kecenderungan makan ikan nila yang hidup di Waduk Wonorejo, Tulungagung, Jawa Timur.

\section{MATERI DAN METODE}

\section{Lokasi Penelitian}

Waduk Wonorejo merupakan salah satu waduk yang terdapat di Kabupaten Tulungagung. Waduk ini merupakan waduk terbesar di Asia Tenggara dengan debit air sebesar $15.000 \mathrm{~m}^{3}$ per detik yang letaknya \pm $15 \mathrm{Km}$ dari pusat kota Tulungagung dengan perbukitan alam yang memiliki hawa sejuk dan dengan tingkat kemiringan lereng serta yang tidak curam. Selain sebagai obyek wisata, waduk Wonorejo ini juga memiliki fungsi sebagai PLTA, irigasi, dan penggerak turbin untuk menghasilkan energi listrik. Lokasi pengambilan sampel di waduk Wonorejo, Kabupaten Tulungagung ini dilakukan di dua titik, yaitu titik pertama (stasiun 1) berada di koordinat ( $8^{\circ} 01^{\prime} 05.0^{\prime} \mathrm{S}$, $\left.111^{\circ} 47^{\prime} 08.2^{\prime \prime} \mathrm{E}\right)$ yang merupakan daerah tempat masuk para wisatawan. Sedangkan pada titik kedua (stasiun 2) berada pada koordinat $\left(8^{\circ} 00^{\prime} 40,8^{\prime \prime} \mathrm{S}, 111^{\circ} 48^{\prime} 11.3\right.$ 'E) yang merupakan lokasi pemancingan umum (fishing ground). Gambar 1.

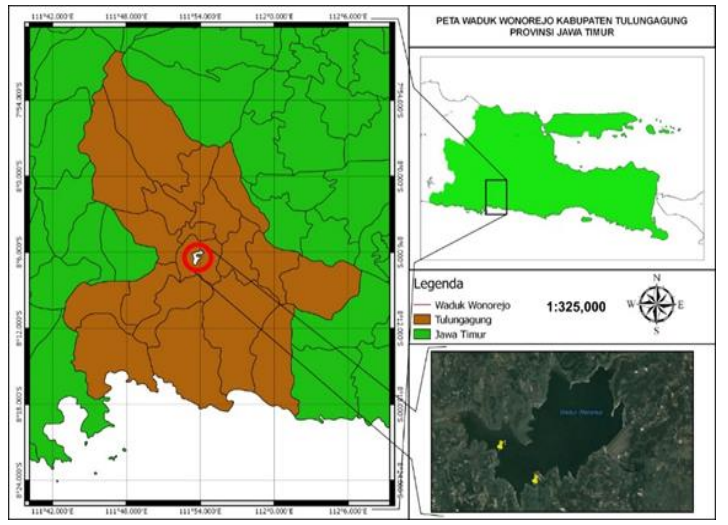

Gambar 1. Lokasi Waduk Wonorejo, Kabupaten Tulungagung

\section{Prosedur}

Persiapan Sampel

Sampel air diambil dengan menggunakan kemmerer water sampler secara komposit sebanyak 2 liter kemudian di simpan ke dalam botol untuk selanjutnya dianalisis di laboratorium. Sedangkan sampel fitoplankton 
diambil dengan cara yang sama dengan pengambilan sampel air namun hanya hingga kedalaman air yang masih terlihat oleh cahaya matahari, agar didapatkan sebaran plankton secara optimal. Pengambilan sampel plankton dilakukan sebanyak 4 kali pengambilan dan disaring dengan plankton net ukuran no. 25 mesh size 64 hingga volume mencapai $25 \mathrm{ml}$. Sampel yang telah disiapkan, di masukkan ke dalam coolbox untuk dilakukan analisis di Laboratorium Reproduksi, Fakultas Perikanan dan Ilmu Kelautan, Universitas Brawijaya, Malang. Pengambilan sampel dilakukan sebanyak 3 kali dengan rentang waktu dua minggu sekali.

\section{Analisis Fisika-Kimia Air}

Fisika dan Kimia Perairan Waduk Wonorejo, Tulungagung dilakukan secara insitu dan ex-situ. Suhu (thermometer raksa), kecerahan, $\mathrm{pH}$ (universal), dan oksigen terlarut (DO) (Lutron tipe PDO-520) dilakukan secara in-situ sedangkan total bahan organik (TOM) dilakukan secara ex-situ di Laboratorium Hidrobiologi, Fakultas Perikanan dan Ilmu Kelautan, Universitas Brawijaya, Malang.

Analisis Plankton

Plankton yang terdapat di perairan Waduk Wonorejo, Tulungagung dianalisis dengan metode Shannon-Wiener index meliputi analisis indeks kelimpahan fitoplankton, indeks keanekaragaman dan indeks dominasi. Sedangkan analisis isi lambung ikan nila dari Waduk Wonorejo, Tulungagung dianalisis dengan cara isi lambung dibedah dan dicuci dengan nafis $0,9 \%$ kemudian air hasil cucian lambung di identifikasi jenis plankton yang terdapat didalam lambung ikan nila tearsebut dengan menggunakan mikroskop binokuler (Olympus CX 21).

Analisis Aktivitas Enzim Lambung Ikan Nila

Aktivitas enzim lambung yang yang dianalisis adalah enzim protease, amilase dan lipase dengan modifikasi metode [11].

\section{HASIL DAN PEMBAHASAN}

\section{Parameter Kualitas Air}

Kualitas air yang dianalisis di Waduk Wonorejo, Tulungagung meliputi parameter fisika (suhu, kecerahan), dan kimia ( $\mathrm{pH}, \mathrm{DO}$, dan TOM) tergolong baik. Data parameter kualitas air dapat dilihat pada Tabel 1.

Tabel 1. Analisis Kualitas Air di Waduk Wonorejo, Tulungagung, Jawa Timur

\begin{tabular}{lcccccc}
\hline \multirow{2}{*}{ Parameter } & \multicolumn{2}{c}{ Ulangan 1 } & \multicolumn{2}{c}{ Ulangan 2 } & \multicolumn{2}{c}{ Ulangan 3 } \\
\cline { 2 - 7 } & 1 & 2 & 1 & 2 & 1 & 2 \\
\hline Suhu $\left({ }^{\circ} \mathrm{C}\right)$ & 26,3 & 26,5 & 26,5 & 26,5 & 27,3 & 26,9 \\
pH & 7 & 7 & 7 & 7 & 7 & 7 \\
DO $(\mathrm{mg} / \mathrm{L})$ & 7,1 & 7,1 & 7,4 & 7,6 & 7,7 & 8,4 \\
$\begin{array}{l}\text { Kecerahan } \\
(\mathrm{cm})\end{array}$ & 110 & 120 & 139 & 130 & 154 & 145 \\
TOM & & & & & & \\
$(\mathrm{mg} / \mathrm{L})$ & 29,1 & 27,8 & 21,5 & 19 & 25,3 & 30,3 \\
\hline
\end{tabular}

Suhu yang terdapat di Waduk Wonorejo masih tergolong baik di kedua stasiun. [12], menyatakan bahwa ikan nila (Oreochromis niloticus) dapat hidup pada kisaran suhu 14$38^{\circ} \mathrm{C}$ dan tumbuh optimal pada suhu $25-30^{\circ} \mathrm{C}$. Kecerahan di kedua stasiun pun tergolong tinggi yaitu diatas $25 \mathrm{~cm}$. [13], menyebutkan bahwa nilai kecerahan yang tinggi ialah diatas $25 \mathrm{~cm}$. pH dan DO yang terdapat di kedua stasiun pun juga tergolong baik. [14], menyebutkan bahwa standar $\mathrm{pH}$ dan DO untuk mutu air kelas dua (sarana atau prasarana rekreasi air, peternakan, pengairan tanaman, budidaya ikan air tawar, dan kegunaan lain yang mensyaratkan mutu air yang sama) yaitu masing-masing 6-9 dan $>4$ $\mathrm{mg} / \mathrm{L}$. Kemudian kadar TOM yang terkandung di perairan tergolong sedang. Kadar TOM di perairan dikategorikan menjadi 3, yaitu $<20 \mathrm{mg} / \mathrm{L}$ dikatergorikan dengan kualitas perairan yang baik, 20-40 $\mathrm{mg} / \mathrm{L}$ dikategorikan dengan kualitas perairan sedang, dan $>40 \mathrm{mg} / \mathrm{L}$ dikategorikan dengan kualitas perairan buruk [15].

\section{Identifikasi Plankton}

Identifikasi Plankton di Waduk Wonorejo Kelimpahan Plankton di Waduk Wonorejo di kedua stasiun ditemukkan 17 genus fitoplankton (Anabaena, Choroococcus, Oscillatoria, Spirulina, Ceratium, Closterium, Staurastrum, Crucigenia, Geminella, Gonatozygon, Scenedesmus, Spirogyra, Microspora, Gyrosigma, Rhopalodia, Synedra, dan Neidium) dan 5 genus 
zooplankton (Branchionus, Keratella, Cyclops, Daphnia, dan Moina). Pada stasiun 1 rata-rata kelimpahan plankton sebanyak 1487 ind $/ \mathrm{ml}$, sedangkan pada stasiun 2 rata-rata kelimpahan plankton sebanyak 746 ind $/ \mathrm{ml}$. Sehingga kedua stasiun tersebut tergolong oligotrofik (tingkat kesuburan rendah). [16], menyebutkan bahwa, perairan oligotrofik memiliki tingkat kesuburan rendah dengan kelimpahan plankton 0-2000 ind/ml, perairan mesotrofik memiliki tingkat kesuburan sedang dengan kelimpahan plankton 2000-15000 $\mathrm{ind} / \mathrm{ml}$, dan perairan eutrofik memiliki tingkat kesuburan tinggi dengan kelimpahan plankton $>15000 \mathrm{ind} / \mathrm{ml}$. Indeks keanekaragaman menunjukkan hsil sebesar 4,32 (stasiun 1) dan 2,45 (stasiun 2) yang berarti pada stasiun 1 keanekaragaman nya tergolong tinggi sedangkan stasiun 2 keanekaragaman nya tergolong sedang. Indeks dominasi di kedua stasiun tergolong rendah yaitu 0,304 pada stasiun 1 dan 0,124 pada stasiun 2 yang berarti bahwa tidak ada genus yang mendominasi karena nilai indeks dominasi nya mendekati angka 0 (nol).

Identifikasi Plankton di Lambung Ikan Nila

Berdasarkan analisis isi lambung ikan nila, ditemukan 30 genus fitoplankton (Anabaena, Chlorella, Choroococcus, Merismopedia, Oscillatoria, Spirulina, Ceratium, Closterium, Cosmarium, Crucigenia, Geminella, Gonatozygon, Scenedesmus, Spirogyra, Staurastrum, Cymbella, Dactyliosolen, Frustulia, Gyrosigma, Navicula, Nitzschia, Pinnularia, Pleurosigma, Rhizosolenia, Rhopalodia, Sticochoccus, Surirella elegans, Synedra, Tabellaria, Thalassionema), 2 genus zooplankton (Arcella dan Keratella), dan 1 filum Anellida). Pada pengambilan sampel pertama dan kedua, ikan nila yang tertangkap di Waduk Wonorejo banyak mengkonsumsi fitoplankton jenis Spirogyra sp. sedangkan pada pengambilan sampel ketiga, ikan nila yang tertangkap di Waduk Wonorejo banyak mengkonsumsi fitoplankton jenis Choroococcus sp.

Perbandingan Kelimpahan Plankton di Waduk Wonorejo dan Lambung Ikan Nila.
Pada lambung ikan nila menunjukkan bahwa urutan plankton yang paling banyak dikonsumsi adalah Spyrogira sp., Choroococcus, Oscillatoria, Geminella, Merismopedia, dan Ceratium. Sedangkan di perairan Waduk Wonorejo urutan kelimpahan plankton tertinggi adalah Spyrogira sp., Geminella, Oscillatoria, dan Neidium.

Choroococcus merupakan salah satu genus fitoplankton yang banyak ditemukan di lambung ikan nila tapi sedikit sekali kelimpahannya di perairan Waduk Wonorejo yaitu berkisar $7 \mathrm{ind} / \mathrm{ml}$. Hal tersebut diduga karena selain ikan nila menyukai jenis plankton tersebut, Choroococus merupakan jenis mikroalga yang bersifat koloni, sehingga ketika ikan nila mengkonsumsi jenis fitoplankton ini, akan langsung mengkonsumsi dalam jumlah yang besar. [17], menyatakan bahwa Choroococcus giganteus termasuk kedalam grup alga koloni. Kemudian genus Arcella, Rhizosolenia, Pleurosigma, Dactyliosolen, Pinnularia, Thalassionema, Sticochoccus, Tabellaria, Cosmarium, Cymbella, Fostulia, Nitzschia, dan Surirella elegans merupakan jenis fitoplankton yang ditemukan sedikit di lambung ikan nila namun tidak ada sama sekali di perairan Waduk Wonorejo. Hal tersebut diduga karena sedikitnya kelimpahan yang ada di peraairan Waduk Wonorejo menyebabkan ikan nila mengkonsumsi jenisjenis plankton yang disebutkan diatas secara keseluruhan.

\section{Aktivitas Enzim Lambung Ikan Nila}

Analisis aktivitas enzim dalam lambung berfungsi untuk mengetahui kemampuan suatu organisme dalam mencerna suatu makanan. Pada penelitian ini, aktivitas enzim dalam lambung yang diukur adalah protease, amilase, dan lipase. Ikan nila merupakan jenis ikan omnivora yang cenderung lebih suka mengkonsumsi fitoplankton. Hal tersebut dibuktikan dengan hasil analisis isi lambung yang mayoritas ditemukan golongan plankton sebagai makanannya utamanya. Berdasarkan analisis aktivitas enzim lambung ikan nila di Waduk Wonorejo Tabel 2. menunjukkan bahwa aktivitas enzim amilase dan lipase 
lebih tinggi jika dibandingkan dengan aktivitas enzim protease.

Tabel 2. Analisis Aktivitas Enzim Lambung Ikan Nila dari Waduk Wonorejo, Tulungagung

\begin{tabular}{|c|c|c|c|}
\hline Sampel & Enzim & Kadar & Satuan \\
\hline \multirow{3}{*}{$\begin{array}{l}\text { Lambung } \\
\text { Ikan Nila }\end{array}$} & Protease & $0,84 \pm 0,02$ & $\begin{array}{l}\mu \mathrm{mol} \text { tirosin/g } \\
\text { enzim menit }\end{array}$ \\
\hline & Amilase & $14,59 \pm 1,07$ & $\begin{array}{l}\mu \text { mol glukosa/ } \\
\text { g enzim menit }\end{array}$ \\
\hline & Lipase & $17,83 \pm 0,14$ & $\begin{array}{l}\mu \mathrm{mol} \text { asam } \\
\text { lemak/g enzim } \\
\text { menit }\end{array}$ \\
\hline
\end{tabular}

Tingginya aktivitas enzim amilase dan lipase yang terkandung di lambung ikan nila tersebut diduga disebabkan oleh faktor makanan yang dikonsumsi oleh ikan nila tersebut. Fitoplankton yang terbanyak ditemukan di lambung ikan nila adalah golongan Spirogyra sp. dimana [18], menyebutkan bahwa komposisi kimia alga Spyrogira sp. mengandung 6-10\% protein, 33$64 \%$ karbohidrat, dan $11-21 \%$ lemak.

\section{KESIMPULAN}

Waduk Wonorejo memiliki kualitas air yang sangat baik berdasarkan standar mutu kualitas air kelas dua (PP RI No. 82 Tahun 2001), akan tetapi tingkat kesuburan nya rendah jika dilihat dari kelimpahan plankton yang ada di perairan tersebut. Ikan nila yang terdapat di Waduk Wonorejo lebih menyukai mengkonsumsi plankton terutama fitoplankton jenis Spirogyra sp. jika dibandingkan dengan makanan selain plankton. Hal tersebut yang menyebabkan tingginya aktivitas enzim amilase dan lipase dan rendahnya aktivitas enzim protease. Sebaiknya, perlu adanya upaya dalam mempertahankan kondisi waduk agar tetap oligotrofik untuk menjaga kualitas perairan tetap baik.

\section{REFERENCES}

[1] Yanuhar U, Musa M, Rahayu DT, Arfiati D. Identification Of Plankton On Fish Pond Of Oreochromis Niloticus Infected By Viral Nervous Necrosis. Research Journal Of Life Science. 2016;3(2):119-28.
[2] Kitamura S-I, Kamata S-I, Nakano S-I, Suzuki S. Detection Of Marine Birnavirus Genome In Zooplankton Collected From The Uwa Sea, Japan. Diseases Of Aquatic Organisms. 2003;54(1):69-72.

[3] George B, Kumar JN, Kumar RN. Study On The Influence Of HydroChemical Parameters On Phytoplankton Distribution Along Tapi Estuarine Area Of Gulf Of Khambhat, India. The Egyptian Journal Of Aquatic Research. 2012;38(3):157-70.

[4] Özbay H. Composition and Abundance of Phytoplankton In Relation To Physical And Chemical Variables In The Kars River, Turkey. 2011.

[5] Chalkia E, Kehayias G. Zooplankton Community Dynamics And Environmental Factors In Lake Ozeros (Greece). Mediterranean Marine Science. 2013;14(3):32-41.

[6] Gürbüzer P, Buyurgan Ö, Tekatli Ç, Altindağ A. Species Diversity And Community Structure Of Zooplankton In Three Different Types Of Water Body Within The Sakarya River Basin, Turkey. Turkish Journal Of Zoology. 2017;41(5):848-59.

[7] Jeppesen E, Jensen JP, Søndergaard M, Lauridsen T, Landkildehus F. Trophic Structure, Species Richness And Biodiversity In Danish Lakes: Changes Along A Phosphorus Gradient. Freshwater Biology. 2000;45(2):20118.

[8] Muirhead JR, Ejsmont- Karabin J, Macisaac HJ. Quantifying Rotifer Species Richness In Temperate Lakes. Freshwater Biology. 2006;51(9):1696709.

[9] Murat K, Fontaneto D, Segers H, ALTINDAĞ A. Temperature And 
Salinity As Interacting Drivers Of Species Richness Of Planktonic Rotifers In Turkish Continental Waters. Journal Of Limnology. 2010;69(2):297304.

[10] BAPPEDA. Kab Tulungagung, 2008. Kabupaten Tulungagung Dalam Angka/Tulungagung Regency In Figures. 2008.

[11] Supriyatna A, Jauhari AA, Holydaziah D. Aktivitas Enzim Amilase, Lipase, Dan Protease Dari Larva Hermetia Illucens Yang Diberi Pakan Jerami Padi. JURNAL ISTEK. 2015;9(2).

[12] Setijaningsih L, Umar C. Pengaruh Lama Retensi Air Terhadap Pertumbuhan Ikan Nila (Oreochromis niloticus) Pada Budidaya Sistem Akuaponik Dengan Tanaman Kangkung [Effect Of Water Retention On The Growth Rate Of Nile Tilapia (Oreochromis Niloticus) In The Aquaponic System Planted Water Spinach (Ipomoea Reptans)]. Berita Biologi. 2015;14(3).

[13] Kordi, M. G dan Tancung A. B., 2005. Pengelolaan Kualitas air. Penerbit Rineka Cipta. Jakarta. 208 hal.

[14] Peraturan Pemerintah R. No. 82 Tahun 2001. Pengelolaan Kualitas Air Dan Pengendalian Pencemaran Air Jakarta.

[15] Effendie H. 2003. Telaah Kualitas Air. Bagi pengelolaan dan Sumberdaya dan Lingkungan Perairan. Kanisius. Yogyakarta. 258 hal.

[16] Landner. 1978. Ecology : The Experimental Analysis of Distribution and Abundance. Harper and Row : New York. $380 \mathrm{hlm}$

[17] Ramadani AH, Wijayanti A, Hadisusanto S, Editors. Komposisi Dan Kemelimpahan Fitoplankton Di Laguna
Glagah Kabupaten Kulonprogo Provinsi Daerah Istimewa Yogyakarta. Prosiding Seminar Biologi; 2013.

[18] Husein Ab, Rohmatin Ed. Produksi Bioetanol Dari Alga (Spirogyra Sp.) Dengan Proses Fermentasi: Institut Teknologi Sepuluh Nopember; 2016. 